\title{
Qual o conhecimento em ressuscitação cardiopulmonar e uso do desfibrilador externo automático por estudantes de medicina?
}

\section{What is the knowledge in cardiopulmonary resuscitation and use of the automatic external defibrillator by medical students?}

Sara Cristine Marques dos Santos ${ }^{1}$, Carlos Eduardo Cardoso², Thais Lemos de Souza Macedo ${ }^{3}$, Ivan Lucas Picone Borges dos Anjos ${ }^{4}$, Esmeralci Ferreira ${ }^{5}$, Eduardo Tavares Lima Trajano ${ }^{6}$, Ivana Picone Borges de Aragão

Como citar esse artigo. dos Santos,

S. C. M; Cardoso, C. E; Macedo, T.

L. S; dos Anjos, I. L. P. B; Ferreira,

E; Trajano, E. T. L; de Aragão, I. P. B. Qual o conhecimento em ressuscitação cardiopulmonar e uso do desfibrilador externo automático por estudantes de medicina? Revista de Saúde 2021 Ago/Nov.; 12 (3): 11-19.

\begin{abstract}
Resumo
A reanimação cardiopulmonar (RCP) consiste em um procedimento onde há a combinação de compressões torácicas e manobras de ventilação, para tentativa de reversão da parada cardiorrespiratória (PCR). O conhecimento do estudante de medicina, na identificação da PCR e manobras de RCP e uso do desfibrilador externo automático (DEA), é importante ser avaliado, permitindo verificar suas aptidões ao atendimento de emergência, contribuindo para salvar vidas, além de torná-los em potenciais multiplicadores do conhecimento. O objetivo do presente estudo foi avaliar o conhecimento do estudante de medicina quanto aos parâmetros para identificação da PCR e para a execução da RCP. Estudo observacional e transversal sobre o conhecimento teórico em RCP, em acadêmicos de medicina, através de um questionário anônimo de respostas rápidas, com análise de dados através dos programas Excel e Minitab. Foi possível observar que a maior parte dos estudantes se considerava capaz de identificar uma vítima em PCR. Porém, metade do total de entrevistados não se considerou capaz de atuar, realizando a RCP. Observa-se que há a necessidade da implementação de módulos de treinamentos práticos para esses alunos, de forma a aumentar a segurança deles para ação.
\end{abstract}

Palavras-chave: Reanimação Cardiopulmonar. Parada Cardíaca. Emergências. Estudantes de Medicina. Conhecimento. Cardioversão Elétrica

\begin{abstract}
Cardiopulmonary resuscitation (CPR) consists of a procedure where there is a combination of chest compressions and ventilation maneuvers, to reverse cardiac arrest (CRA). The medical student's knowledge in CPR identification, CPR maneuvers and automatic external defibrillator (AED) use is important to be evaluated, allowing to verify their emergency care skills, contributing to save lives, besides making them potential knowledge multipliers. The aim of the present study was to evaluate medical students' knowledge regarding the parameters for CPR identification and CPR performance. This was an observational and cross-sectional study of medical students' theoretical knowledge of CPR, using an anonymous short-answer questionnaire and data analysis using Excel and Minitab software. It was possible to observe that most students considered themselves capable of identifying a victim in CPR. However, half of the total number of interviewees did not consider themselves capable of performing CPR. It is observed that there is a need for the implementation of practical training modules for these students, to increase their safety for action.
\end{abstract}

Keywords: Cardiopulmonary resuscitation; Cardiac arrest; Emergencies; Medical students; Knowledge; Electric Cardioversion

\section{Introdução}

Historicamente, os termos ataque cardíaco ou heart attack, na língua inglesa, e parada cardíaca/parada cardiorrespiratória (PCR) ou cardiac arrest, vêm sendo usados como se fossem sinônimos, mas não o são ${ }^{1,2}$. O termo ataque cardíaco vem sendo usado em menção à ocorrência de isquemia até necrose miocárdica, quando não revascularizado química ou cirurgicamente ${ }^{1,2}$.

O infarto agudo do miocárdio (IAM) é o grande exemplo do uso do termo ataque cardíaco, no qual há manutenção da atividade contrátil do miocárdio e de sua funcionalidade, independentemente, do déficit segmentar do miocárdio ${ }^{1,2}$.

A PCR tem sua fundamentação patológica na súbita interrupção da funcionalidade cardíaca contrátil

Afiliação dos autores:

${ }^{1}$ Estudante do curso de Medicina e do projeto de pesquisa na Universidade de Vassouras, RJ, Brasil. ORCID: https://orcid.org/0000-0002-8205-8112.

${ }^{2}$ Doutor em Ciências pela PUC-RJ, Professor titular da Universidade de Vassouras, Docente do Mestrado Profissional em Ciências Aplicadas em Saúde, Universidade de Vassouras, Vassouras, RJ, Brasil. ORCID: https://orcid.org/0000-0002-1948-600X.

${ }^{3}$ Estudante do curso de Medicina e do projeto de pesquisa na Universidade de Vassouras, RJ, Brasil. ORCID: https://orcid.org/0000-0002-7667-6061

${ }^{4}$ Estudante do curso de Medicina e do projeto de pesquisa na Universidade de Vassouras, RJ, Brasil. ORCID: https://orcid.org/0000-0003-4211-1887.

${ }^{5}$ Doutor em cardiologia pela Universidade do Estado do Rio de Janeiro, Médico e professor Associado do curso de medicina e do Programa de Pós-Graduação em Ciências Médicas da Universidade do Estado do Rio de Janeiro, Rio de Janeiro, Brasil. ORCID: https://orcid.org/0000-0003-3230-7683.

${ }^{6}$ Doutor em Fisioterapia pela Universidade Federal do Rio de Janeiro, Professor adjunto II do curso de Medicina e Coordenador do Mestrado Profissional em Ciências Aplicadas em Saúde (Medicina III- urgência e emergência), Universidade de Vassouras, Vassouras, RJ, Brasil. ORCID: https://orcid.org/0000-0001-7809-7138

${ }^{7}$ Médica e doutora em cardiologia pela Universidade Federal do Rio de Janeiro, Médica e professora adjunta II do curso de Medicina e do Mestrado em Profissional em Ciências

Aplicadas em Saúde (Medicina III- urgência e emergência) da Universidade de Vassouras, Vassouras, RJ, Brasil. ORCID: https://orcid.org/0000-0002-4295-0165.

* Email de correspondência: saracrismarques@icloud.com

Recebido em: 27/03/2021. Aceito em: 16/10/2021. 
como bomba, seja por taquicardia ventricular (TV) ou fibrilação ventricular (FV), seja por assistolia ventricular, havendo interrupção do fluxo sanguíneo para órgãos vitais. Apesar das diferenças, ambos podem estar interligados, uma vez que o IAM constitui uma das causas de $\mathrm{PCR}^{3}$.

Nos últimos 10 anos, no Brasil, segundo Departamento de Informática do Sistema Único de Saúde (DATASUS) foram registradas 3.141.054 internações por doenças isquêmicas miocárdicas e arritmias cardíacas, com taxa de mortalidade (TXM) de 6,75\% (212.007 óbitos) $)^{4}$.

Em 1874, houve início da massagem cardíaca, para reanimação, através da técnica em peito aberto, sendo usado até a segunda metade do século XX, época em que foi demonstrado que a forma não invasiva era equivalente ${ }^{5}$. Nesse período, houve as publicações de Kouwenhoven, sobre uso da compressão torácica e de Peter Safar sobre a abertura de vias aéreas aliados à compressão torácica ${ }^{6}$ e, em conjunto com James Jude, houve o início do que hoje denominamos ressuscitação cardiopulmonar (RCP), sendo publicado o primeiro guia de Advanced Cardiovascular Life Suport pela American Heart Association (AHA) ${ }^{7}$.

Claude Beck, em 1947, iniciou a cardioversão elétrica em humanos com sucesso, através da técnica de peito aberto, a qual evoluiu, alguns anos depois, para o uso externo ${ }^{7}$. Registros brasileiros de 2019, 2018 e 2017, disponibilizados pela Secretaria em Vigilância em Saúde, identificaram 751, 744 e 833 casos de PCR de origem cardíaca, sendo $>50 \%$ em domicílio, seguidos por hospitais, outras unidades de saúde e via pública ${ }^{8}$.

O prognóstico da PCR está diretamente relacionado ao correto reconhecimento, ação rápida e execução das manobras de RCP, auxiliado pelo uso do algoritmo das cadeias de sobrevivência intra e extrahospitalar, propostos pela $\mathrm{AHA}^{9-11}$.

A importância da associação das manobras de RCP ao desfibrilador externo automático (DEA) é fundamentada forma de PCR em FV/TV. A persistente ausência circulatória é responsável por dano ao miocárdio e redução da eficiência e efetividade da desfibrilação, podendo variar desde $31 \%$ até mais que $70 \%$ de sobrevivência, quando aplicada no primeiro minuto. A cada minuto de atraso, decai $10 \%{ }^{12,13}$.

As compressões torácicas possibilitam a perfusão sanguínea e transporte de fármacos e oxigênio para órgãos vitais, interferindo, positivamente, no prognóstico neurológico ${ }^{14}$.

A Sociedade Brasileira de Cardiologia (SBC) recomenda a política de desfibrilação precoce e ressalta a necessidade de considerá-la como assunto de saúde, atuando juntamente ao Fundo de Aperfeiçoamento e Pesquisa em Cardiologia (FUNCOR) na capacitação dos profissionais de saúde ${ }^{15,16}$.

Em 2004, no Brasil, foi decretado a obrigatoriedade da instalação do DEA, em locais onde a circulação de mais de 2000 pessoas/dia, meios de transporte com mais que 100 passageiros e veículos de emergência, sujeito a sanções penais e administrativas ${ }^{14,17,18}$.

$\mathrm{O}$ registro de PCR em ambiente extra-hospitalar (PCREH) demonstrou a necessidade de treinamento em massa para a população, não somente para aqueles que integram a rede de assistência, aumentando as chances de sobrevivência das vítimas, com aplicação de RCP e DEA, disponibilizados em locais públicos19,20. Alguns países implantaram a capacitação em nível escolar ${ }^{21}$.

Alunos de medicina treinados estão aptos ao atendimento de emergência sem risco pessoal e à vítima, além do potencial multiplicador do conhecimento, seja em ambiente domiciliar, entre amigos, pares ou outros círculos sociais, contribuindo para salvar vidas.

Portanto, o objetivo do presente estudo foi analisar o conhecimento acerca das manobras de ressuscitação cardiopulmonar e utilização do desfibrilador externo automático por acadêmicos de medicina, de modo a avaliar o quão aptos eles estão para atuar em uma parada cardiorrespiratória, permitindo identificar quais pontos são lacunas a serem preenchidas ao longo de sua formação acadêmica.

\section{Métodos}

Estudo observacional e transversal sobre o conhecimento teórico em RCP, por acadêmicos de medicina, através de um questionário anônimo, com 25 perguntas de respostas rápidas, aplicados entre $2018 \mathrm{e}$ 2020, após assinatura do termo de consentimento livre e esclarecido (TCLE). Houve aprovação do Comitê de Ética em Pesquisa (CEP) Parecer no 2.971.794. Foram inclú́dos alunos matriculados no curso de medicina, independentemente da idade, sexo ou cor e, excluídos, aqueles matriculados em outros cursos.

Para a construção do questionário, foram utilizados artigos selecionados nos sites de busca científica PUBMED e SciELO, publicados entre 2007 e 2015, nos idiomas português e inglês. Os Descritores em Ciência da Saúde, utilizados foram "Reanimação Cardiopulmonar"; "Parada Cardíaca" e "Coração".

As perguntas do questionário avaliaram os seguintes parâmetros, sobre o conhecimento em RCP: tempo $<05$ minutos para considerar a PCR reversível; elos da cadeia de sobrevivência PCREH estabelecidos pela AHA; pulso a ser verificado; manuseio do DEA, onde aprendeu a utilizar e quais os ambientes em que foram identificados; identificação da diferença entre ritmos cardíacos chocáveis/não chocáveis; conduta nos diferentes ritmos cardíacos; localização correta da compressão torácica; posição correta do socorrista; posicionamento das mãos no socorrista na compressão 
torácica; superfície ideal para repousar a vítima enquanto recebe a RCP; profundidade das compressões torácica em adultos e crianças; intervalo de tempo para reavaliar o pulso na vítima; momento do uso do DEA; se há diferença entre atendimentos em gestantes; transporte à unidade hospitalar; qual nome e número do telefone do serviço médico de emergência (SME) a ser acionado; fatores responsáveis pela diminuição do índice de sobrevivência; autopercepção sobre identificar PCR e sobre a sua aptidão.

Os dados obtidos foram inseridos em planilha eletrônica no software Excel. Cada pergunta correspondeu a uma variável a ser avaliada. O grupo autodeclarado "apto" a realização da RCP foi posteriormente relacionado com as outras variáveis. Considerado inapto, aqueles que desconheciam a resposta correta ou responderam incorretamente.

A análise estatística foi realizada com auxílio do programa Minitab, por meio de teste $t$ de Student Pareado e da análise da variância (ANOVA). Em todos os cálculos, foi adotado um nível de significância de $95 \%$.

\section{Resultados}

Entre 2018 e 2020, 300 alunos do curso de medicina responderam aos questionários sobre RCP. A maioria dos alunos, 225(75\%), responderam corretamente sobre o primeiro elo ser o reconhecimento de uma PCR e o imediato acionamento do SME, outros $36(12 \%)$ responderam que o início imediato das manobras de RCP de alta qualidade, $35(11,67 \%)$ desconheciam e $04(1,33 \%)$ não responderam (Figura 1 e tabela 1$)$.

O segundo elo da cadeia de sobrevivência, que

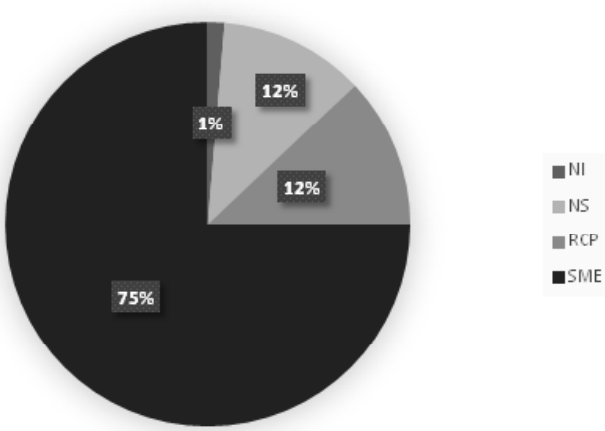

Figura 1. Conhecimento do primeiro elo da parada cardiorrespiratória extra-hospitalar. Legenda: NI- não informou; NS- não sabe; RCP- ressuscitação cardiopulmonar; SME- serviço médico de emergência.

Tabela 1. Respostas a respeito do manejo da RCP.

\begin{tabular}{|c|c|c|c|c|c|}
\hline \multicolumn{6}{|c|}{ CONHECIMENTO E MANEJO DE ASPECTOS DA RCP } \\
\hline \multirow{3}{*}{$\begin{array}{l}\text { A partir de quantos minutos a } \\
\text { PCR pode ser considerada } \\
\text { irreversível? }\end{array}$} & $5 \mathrm{~min}$ & \multicolumn{2}{|r|}{$10 \mathrm{~min}$} & Não sabe & Não informou \\
\hline & 87 & \multicolumn{2}{|r|}{134} & 73 & 6 \\
\hline & $(29 \%)$ & & $(44,67 \%)$ & $(24,33 \%)$ & $(2 \%)$ \\
\hline \multirow{3}{*}{$\begin{array}{c}\text { A RCP em gestante para você tem } \\
\text { alguma diferença? }\end{array}$} & Sim & \multicolumn{2}{|r|}{ Não } & Não sabe & Não informou \\
\hline & 172 & \multicolumn{2}{|r|}{31} & 79 & 18 \\
\hline & $(57,33 \%)$ & \multicolumn{2}{|r|}{$(10,33 \%)$} & $(26,33 \%)$ & $(6 \%)$ \\
\hline \multirow{3}{*}{$\begin{array}{l}\text { A profundidade das compressões } \\
\text { em adultos deve ser de? }\end{array}$} & $5 \mathrm{a} 6 \mathrm{~cm}$ & $4 \mathrm{~cm}$ & Tudo & Não sabe & Não informou \\
\hline & 231 & 21 & 7 & 22 & 19 \\
\hline & $(77 \%)$ & $(7 \%)$ & $(2,33 \%)$ & $(7,33 \%)$ & $(6,33 \%)$ \\
\hline \multirow{3}{*}{$\begin{array}{l}\text { A profundidade das compressões } \\
\text { em crianças deve ser de? }\end{array}$} & 5 a $6 \mathrm{~cm}$ & $4 \mathrm{~cm}$ & Tudo & Não sabe & Não informou \\
\hline & 32 & 164 & 4 & 85 & 15 \\
\hline & $(10,67 \%)$ & $(54,67 \%)$ & $(1,33 \%)$ & $(28,33 \%)$ & $(5 \%)$ \\
\hline \multirow[t]{3}{*}{ O pulso a ser verificado na vítima } & Carotídeo & Radial & Braquial & Não sabe & Não informou \\
\hline & 234 & 33 & 4 & 24 & 5 \\
\hline & $(78 \%)$ & $(11 \%)$ & $(1,33 \%)$ & $(8 \%)$ & $(1,67 \%)$ \\
\hline \multirow{3}{*}{$\begin{array}{l}\text { Havendo o restabelecimento da } \\
\text { vítima, deve-se reavaliar a } \\
\text { presença de pulso em: }\end{array}$} & $2 \min$ & $5 \mathrm{~min}$ & $10 \mathrm{~min}$ & Não sabe & Não informou \\
\hline & 132 & 40 & 14 & 95 & 19 \\
\hline & $(44 \%)$ & $(13,33 \%)$ & $(4,67 \%)$ & $(31,67 \%)$ & $(6,33 \%)$ \\
\hline
\end{tabular}


é a realização de RCP imediata de alta qualidade, foi identificado por $211(70,33 \%)$ alunos, seguidos de $42(14 \%)$ que afirmaram ser a rápida desfibrilação, $44(14 \%)$ desconheciam e $03(1 \%)$ não responderam (Figura 2 e tabela 1 ).

Mais de um terço dos alunos, 234 (78\%), conhecia ser o pulso carotídeo, o utilizado como parte do processo de diagnóstico da PCR, seguidos de 33 (11\%) que

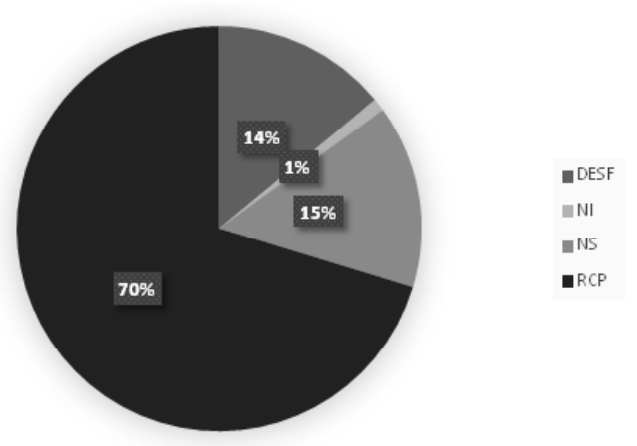

Figura 2. Conhecimento do segundo elo da parada cardiorrespiratória extra-hospitalar.

Legenda: DESF- desfibrilação; NI- não informou; NS- não sabe; RCP- ressuscitação cardiopulmonar reportaram ser o pulso radial, $04(1,33 \%)$ o braquial, 24 (8\%) desconheciam e $05(1,67 \%)$ não responderam.

A grande maioria do grupo, $263(87,67 \%)$ alunos, informou que conhecia o que é um DEA, sendo identificado que esse grupo conhecia as indicações ao uso do aparelho $(\mathrm{p}<0,005)$. A minoria de $36(12 \%)$ alunos desconheciam o DEA e $01(0,33 \%)$ não respondeu (tabela 2) e (tabela 3).

Tabela 3. Dados estatísticos das respostas de aptidão de manuseio do DEA com as respostas corretas.

\begin{tabular}{|c|c|c|}
\hline \multicolumn{3}{|c|}{$\begin{array}{l}\text { AVALIAÇÃO DO CONHECIMENTO DE USO DO DEA } \\
\text { GRUPO TOTAL }=\mathbf{3 0 0}(\mathbf{1 0 0} \%) \text { ALUNOS }\end{array}$} \\
\hline \multicolumn{3}{|c|}{ APTOS = $171(57 \%)$} \\
\hline \multicolumn{3}{|c|}{ NÃO APTOS = $129(53 \%)$} \\
\hline RESPOSTA CORRETA & $\mathbf{P}$ & IC $95 \%$ \\
\hline $\begin{array}{l}\text { Momento correto do uso do DEA na RCP } \\
\qquad 101(33,67 \%)\end{array}$ & $\mathrm{p}<0,001$ & 0,16579 e 0,30088 \\
\hline $\begin{array}{c}\text { Correlação do ritmo encontrado pelo DEA e } \\
\text { a RCP } \\
124(41,33 \%)\end{array}$ & $\mathrm{p}<0,001$ & 0,097298 e 0,21604 \\
\hline $\begin{array}{l}\text { Conduta de acordo com o ritmo encontrado } \\
\qquad 198(66 \%)\end{array}$ & $\mathrm{p}<0,008$ & $-0,15655$ e $-0,023454$ \\
\hline
\end{tabular}

Tabela 2. Respostas a respeito do uso do desfibrilador externo automático (DEA).

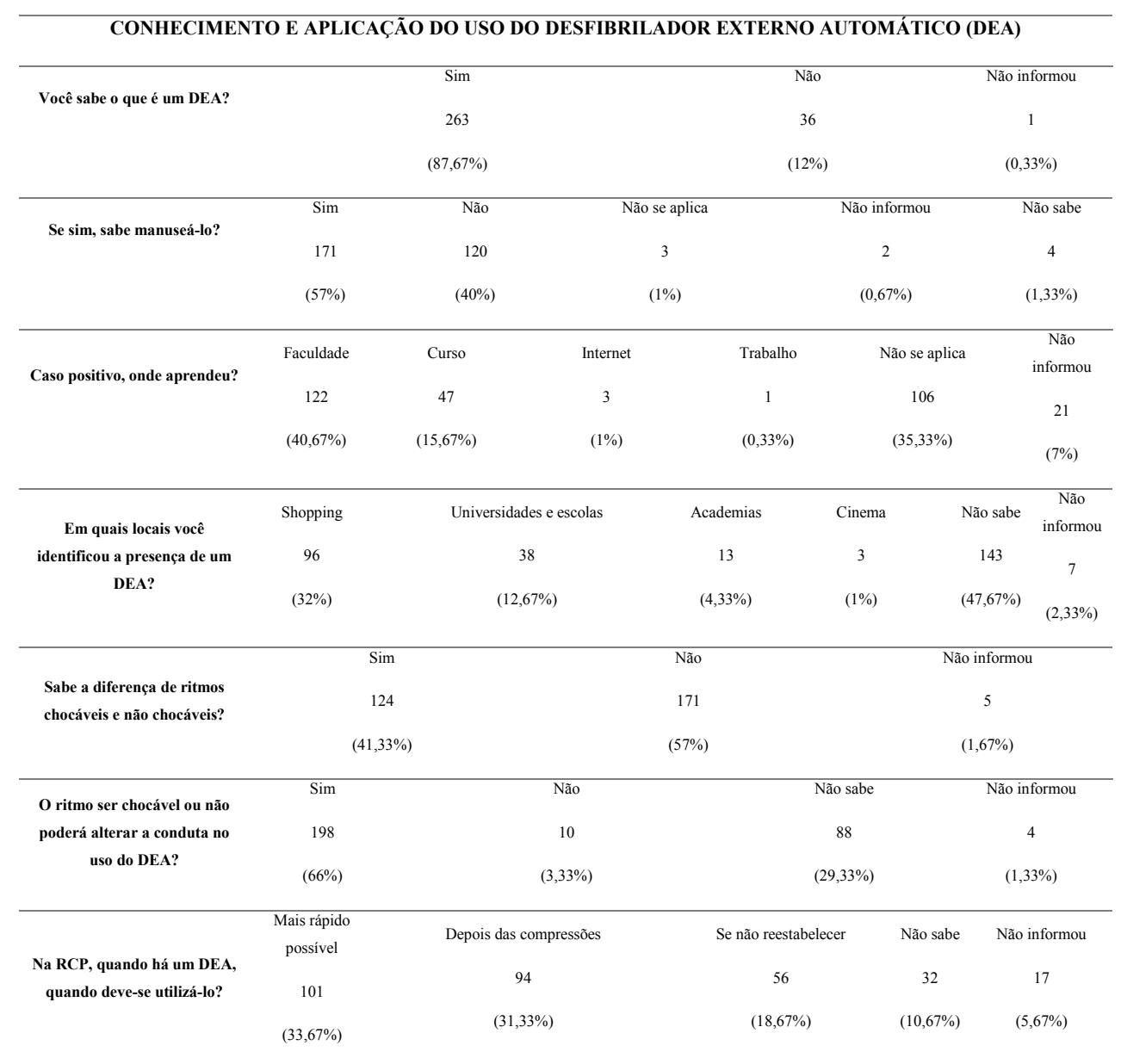


Pouco mais da metade, 171 (57\%) alunos, afirmou saber manusear o DEA, enquanto 120 (40\%) desconheciam e 09 (03 \%) que o questionamento não se aplicava (Figura 3 e tabela 2).

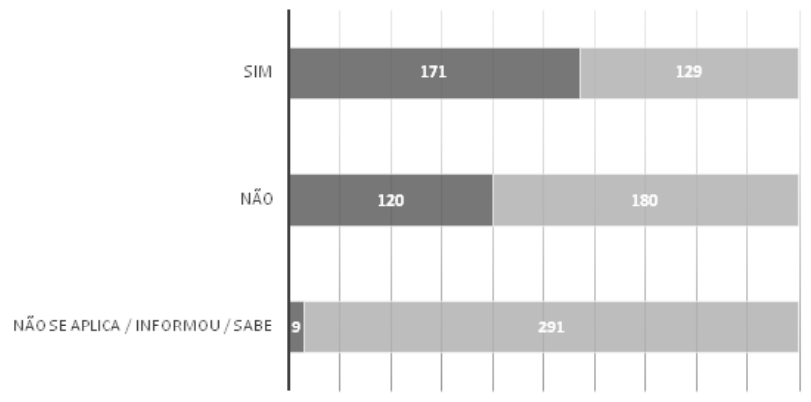

Figura 3. Uso do desfibrilador externo automático pelos entrevistados.

Os alunos reportaram ter aprendido manusear o DEA durante o curso de graduação em $122(40,67 \%)$ casos, $47(15,67 \%)$ em cursos externos, $03(1 \%)$ na internet e $01(0,33 \%)$ no trabalho. Contudo, próximo da metade, 127 (42,33\%), não souberam responder ou disseram que a questão não se aplicava, (Figura $4 \mathrm{e}$ tabela 2).

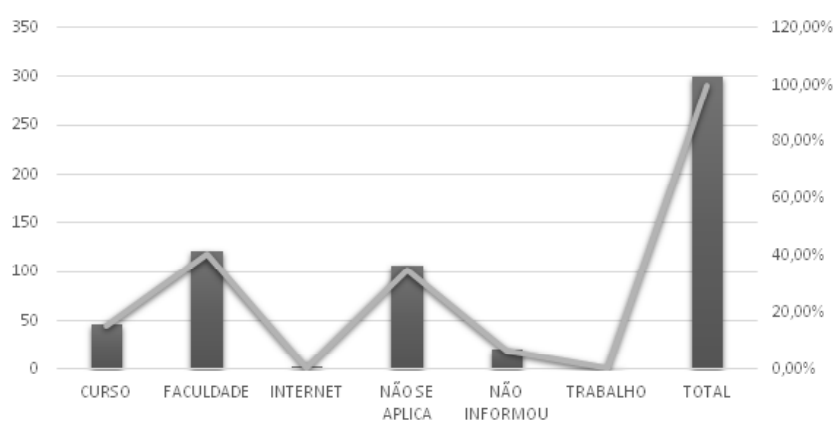

Figura 4. Local de aprendizado do uso do desfibrilador externo automático.

A disponibilização do DEA em locais públicos, como shopping centers, foi identificada por $96(32 \%)$ alunos, $38(12,67 \%)$ em escolas e universidades, 13 $(4,33 \%)$ em academias para exercício físico, 03 (1\%) em cinemas e 07 (2,33\%) não responderam. Porém, 143 $(47,67 \%)$ alunos afirmaram nunca terem identificado um DEA nos locais citados no questionário (tabela 2).

Um total de 171(57\%) alunos desconheciam a diferença entre ritmos cardíacos chocáveis e não chocáveis no atendimento da vítima em PCR. Adicionalmente, 124 (41,33\%) afirmaram conhecer esta diferença e 05 (1,67\%) não responderam (tabela 2).

Ainda em relação ao ritmo cardíaco, 98 (66\%) alunos responderam corretamente que o ritmo encontrado poderá alterar a conduta do atendimento à vítima, $10(3,33 \%)$ responderam que não haveria diferença, 88 (29,33\%) que desconheciam e $04(1,33 \%)$ não responderam esta questão.

As respostas daqueles que se consideraram aptos diferiram estatisticamente das respostas corretas (95\%) (tabela 3). O teste $t$ de Student (teste pareado) revelou que existe diferença significativa entre as médias $(\mathrm{p}<$ $0,005)$. Por outro lado, em um nível de confiança de $95 \%$, é possível ter $95 \%$ de confiança de que o valor real do índice de capacidade esteja contido dentro do intervalo de confiança calculado $(0,020388$ e 0,15295$)$ (tabela 4).

Tabela 4. Dados estatísticos das respostas de aptidão a realização da $\mathrm{RCP}$ com as respostas corretas.

\begin{tabular}{|c|c|c|}
\hline \multirow{2}{*}{\multicolumn{3}{|c|}{$\begin{array}{c}\text { AVALIAÇÃO DO CONHECIMENTO DA TÉCNICA DE REANIMAÇÃO } \\
\text { CARDIOPULMONAR RCP } \\
\text { GRUPO TOTAL }=\mathbf{3 0 0}(\mathbf{1 0 0} \%) \text { ALUNOS }\end{array}$}} \\
\hline & & \\
\hline \multicolumn{3}{|c|}{ APTOS $=150(50 \%)$} \\
\hline \multicolumn{3}{|c|}{ NÃO APTOS = $150(50 \%)$} \\
\hline RESPOSTA CORRETA & $\mathbf{P}$ & IC $95 \%$ \\
\hline $\begin{array}{l}\text { Autodeclarados aptos a identificar uma } \\
\text { PCR }\end{array}$ & $\mathrm{p}<0,001$ & 0,24939 e 0,35728 \\
\hline $241(80,33 \%)$ & & \\
\hline $\begin{array}{l}\text { Profundidade em crianças } \\
\qquad 32(10,67 \%)\end{array}$ & $\mathrm{p}<0,001$ & 0,32909 e 0,45757 \\
\hline $\begin{array}{l}\text { Profundidade em adultos } \\
\qquad 231(77 \%)\end{array}$ & $\mathrm{p}<0,001$ & $-0,34978$ e $-0,22360$ \\
\hline $\begin{array}{l}\text { Reversibilidade da PCR } \\
\qquad 87(29 \%)\end{array}$ & $\mathrm{p}<0,001$ & 0,13288 e 0,28712 \\
\hline $\begin{array}{c}\text { Primeiro elo PCREH } \\
225(\mathbf{7 5} \%)\end{array}$ & $\mathrm{p}<0,001$ & $-0,32023$ e $-0,17977$ \\
\hline $\begin{array}{c}\text { Segundo elo PCREH } \\
211(70,33 \%)\end{array}$ & $\mathrm{p}<0,001$ & $-0,27367$ e $-0,13299$ \\
\hline $\begin{array}{l}\text { Pulso correto } \\
234 \text { (78\%) }\end{array}$ & $\mathrm{p}<0,001$ & $-0,34454$ e $-0,21546$ \\
\hline $\begin{array}{l}\text { Reavaliação da presença de pulso } \\
132(44 \%)\end{array}$ & $\mathrm{P}<0,109$ & $-0,013439$ e 0,13344 \\
\hline $\begin{array}{l}\text { RCP em gestantes } \\
172(57,33 \%)\end{array}$ & $\mathrm{p}<0,055$ & $-0,14836$ e 0,0016958 \\
\hline $\begin{array}{l}\text { Ritmo encontrado na vítima e conduta } \\
\qquad(41,33 \%)\end{array}$ & $\mathrm{P}=0,011$ & 0,20388 e 0,15295 \\
\hline $\begin{array}{c}\text { Superfície para realização da RCP } \\
266(88,67 \%)\end{array}$ & $\mathrm{p}<0,001$ & $-0,44512$ e $-0,32821$ \\
\hline $\begin{array}{c}\text { Posição do socorrista } \\
262(87,33 \%)\end{array}$ & $\mathrm{p}<0,001$ & $-0,43290$ e $-0,31377$ \\
\hline
\end{tabular}

Foram documentadas $243(81 \%)$ respostas sobre a correta localização de dois dedos acima do apêndice xifoide, para a a realização das compressões torácicas na RCP, enquanto $32(10,67 \%)$ responderam que a região seria o lado esquerdo anterior do tórax, 23 (7,67\%) desconheciam e $02(0,66 \%)$ não responderam.

O posicionamento correto das mãos usando a região hipotênar da mão dominante com os dedos entrelaçados era conhecido por $268(89,33 \%)$ alunos, havendo $02(0,67 \%)$ que responderam que uma mão ficava ao lado da outra e aberta, $02(0,67 \%)$ com uma 
mão ao lado da outra fechada, 13 (4,33\%) desconheciam e 15 (5\%) não responderam.

O posicionamento correto do socorrista ao lado da vítima foi reconhecido por $262(87,33 \%)$ alunos, 08 $(2,67 \%)$ responderam "em frente à vítima", $05(1,67 \%)$ "atrás da vítima", 08 (2,67\%) desconheciam e 17 $(5,67 \%)$ não responderam.

Entre aqueles que se reconheciam como aptos ao procedimento da RCP, havia o conhecimento do correto posicionamento das mãos e do socorrista, de forma significativa entre as médias $(\mathrm{p}<0,005)$.

A real necessidade de superfície rígida e plana para realização da RCP foi reconhecida por 266 $(88,67 \%)$ alunos, $05(1,67 \%)$ como não, 14 (4,67\%) desconheciam e 15 (5\%) não responderam.

Um total de $172(57,33 \%)$ estudantes afirmaram corretamente que a RCP em gestantes tem alguma diferença, $31(10,33 \%)$ afirmaram não haver, 79 $(26,33 \%)$ desconheciam e $18(6 \%)$ não responderam (tabela 1).

A correta profundidade de cinco a seis centímetros, para as compressões torácicas em adultos, foi verificada em 231 (77\%) estudantes, enquanto $21(7 \%)$ quatro centímetros, 07 (2,33\%) comprimir o máximo possível, 22 (7,33\%) desconheciam e 19 $(6,33 \%)$ não responderam (Figura 5 e tabela 1$)$.

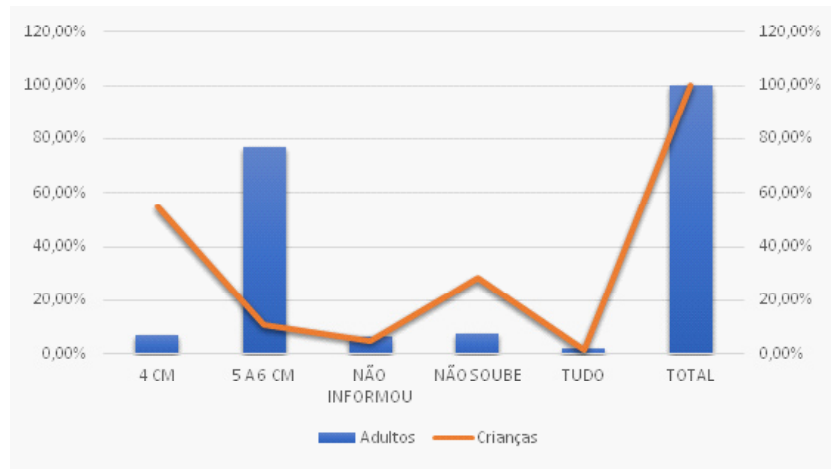

Figura 5. Comparação de respostas sobre profundidade de compressão em adultos e crianças.

Quando se comparou as respostas daqueles que se consideraram aptos com as respostas corretas acerca das manobras, observou-se que existe diferença significativa entre as médias $(\mathrm{p}<0,005)$ com $95 \%$ de confiança $(0,34978$ e 0,22360$)$ (tabela 3$)$.

No caso de PCR em crianças, $32(10,67 \%)$ estudantes responderam corretamente que a profundidade para as compressões torácicas é de cinco a seis centímetros, $164(54,67 \%)$ de quatro, 04 $(1,33 \%)$ comprimir tudo que for possível, 85 (28,33\%) desconheciam e 15 (5\%) não responderam (Figura 5 e tabela 2).

O intervalo de tempo correto de dois minutos para reavaliação do restabelecimento do pulso durante as manobras de RCP na PCR foi reconhecido por 132 (44\%) estudantes, seguidos por $40(13,33 \%)$ de 05 minutos, 14 $(4,67 \%)$ de 10 minutos, 95 (31,67\%) desconheciam e $19(6,33 \%)$ não responderam (tabela 1). A análise dos dados indicou que não existem evidências suficientes para se afirmar que existe diferença significativa entre as médias $(p>0,005)$ em relação as respostas dos que se consideraram aptos e as respostas corretas (literatura). Ainda com relação a presença de pulso, em um nível de confiança de $95 \%$, é possível afirmar (95\% de confiança) que o valor real do índice de capacidade esteja contido dentro do intervalo de confiança calculado $(-0,013439$ e 0,13344 ).

Apenas $87 \quad(29 \%)$ alunos responderam corretamente, sobre o intervalo de tempo em que a PCR é considerada irreversível ser de cinco minutos, seguidos de 73 (24,33\%) que informaram desconhecer e $6(2 \%)$ que não responderam (tabela 1$)$.

A utilização do DEA, o mais precocemente possível, foi reconhecida por $101(33,67 \%)$ estudantes, $94(31,33 \%)$ após as compressões, $56(18,67 \%)$ somente se a vítima não se reestabelecer, $32(10,67 \%)$ desconheciam e 17 (5,67\%) não responderam (tabela 2).

Quando se comparou as respostas daqueles que se consideraram aptos, observou-se que existe diferença significativa entre as médias em relação ao uso do DEA. Um terço do grupo informou conhecer o momento correto para o uso do DEA ( $\mathrm{p}<0,0001$ - IC95\% 0,16579 e 0,30068 ), sendo que menos da metade dos alunos sabia identificar a correção entre o ritmo cardíaco demonstrado ( $p<0,0001$ - IC95\% 0,097298 e 0,21604). Porém, mais da metade conhecia a conduta a ser tomada de acordo com o ritmo encontrado (tabela 3 ).

Mais de um terço, 229 (76,33\%) alunos, conhecia a necessidade da vítima ser transportada, o mais rápido possível, outros $08(2,67 \%)$ não havia necessidade de rápido transporte, $23(7,67 \%)$ somente se a vítima não se reestabelecer, 21 (7\%) desconheciam e $19(6,33 \%)$ não responderam.

Quase todo o grupo, 275 (91,67\%) alunos declararam que acionariam o Serviço de Atendimento Móvel de Urgência (SAMU) e 06 (2\%) Corpo de Bombeiros Militar (CBM), o restante desconhecia ou não respondeu.

O número informado para acionamento do SAMU foi o 192, por $238(79,33 \%)$ estudantes, o 193 para o CBM por $30(10 \%)$. O restante identificou números errados ou não responderam.

Um total de $241 \quad(80,33 \%)$ estudantes se consideraram capazes de identificar uma vítima em PCR (Figura 6), em contraposição, 41 (13,67\%) incapazes e $18(6 \%)$ não responderam. Metade do grupo tinha a percepção de estarem aptos a realizar uma RCP em emergência, 135 (45\%) negaram aptidão e 15 (5\%) não 
responderam (Figura 7 e tabela 4).

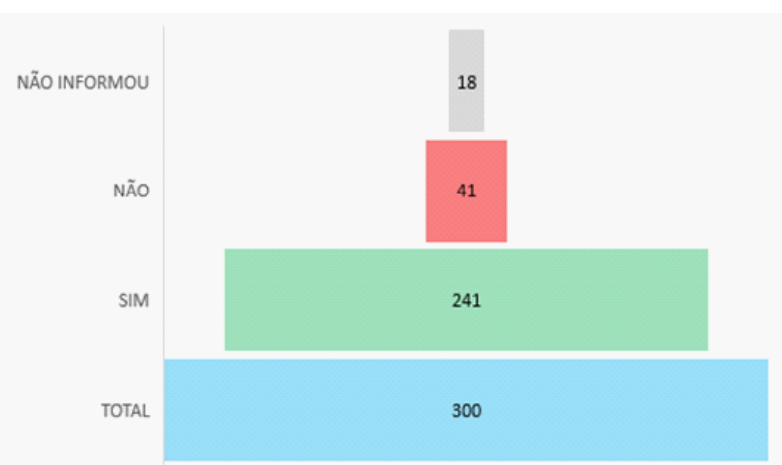

Figura 6. Autopercepção sobre reconhecimento de parada cardiorrespiratória.

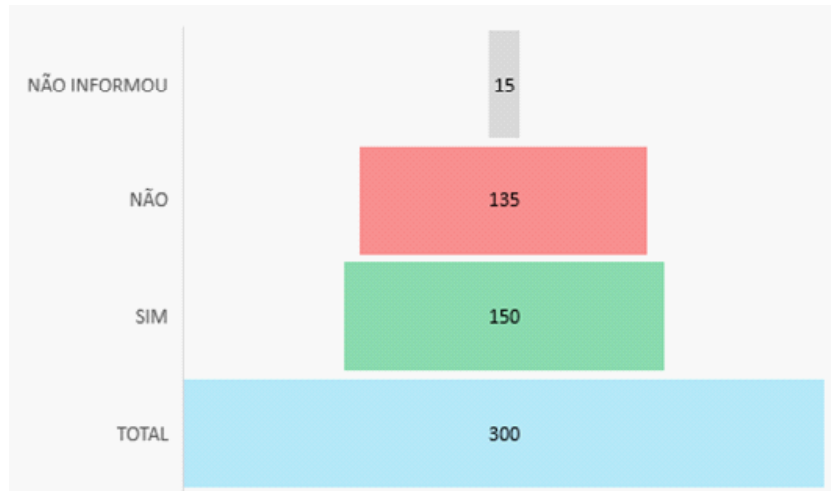

Figura 7. Autopercepção sobre aptidão para realizar ressuscitação cardiopulmonar em situação de emergência.

\section{Discussão}

O retardo no reconhecimento do primeiro elo da cadeia de sobrevivência, que consiste em acionar o serviço de emergência, pode reduzir de forma significativa as chances de sobrevivência da vítima de $\mathrm{PCR}^{22}$.

Portanto, a correta identificação da PCR é a base para que haja o precoce acionamento dos serviços de emergência, através das centrais telefônicas disponibilizadas, além das possíveis orientações ao socorrista leigo no atendimento à vítima ${ }^{22}$.

No presente estudo, mais de dois terços do grupo avaliado informou que ser capaz de reconhecer uma vítima em PCR. Entre eles, 78\% conhecia ser a artéria carotídea, o local correto no reconhecimento da PCR e durante a RCP.

Porém, $<50 \%$ do grupo reconheceu o intervalo de dois minutos de RCP como ideal para a reavaliação do pulso, entretanto, menos de um terço identificou que a PCR é considerada irreversível após cinco minutos de manobras de RCP.

A respiração agonal pode ter relação com o atraso na identificação da PCR, podendo ser interpretada como normal e, consequentemente, gerando falha na correta transmissão das informações telefônicas ao SEM, atraso no atendimento à vítima e agravo no prognóstico ${ }^{23}$.

Além da rapidez no atendimento às vítimas de PCR, os que aguardam os SEM recebendo as manobras de RCP demonstraram maior sobrevivência, ressaltando aqueles com fibrilação ventricular ${ }^{24-26}$.

Outro ponto importante é o protocolo de desfibrilação cardíaca precocemente, sendo portanto ${ }^{27}$, necessário que o socorrista seja capacitado a utilizar o DEA em uma emergência. Durante a análise dos questionários desse estudo com uma população selecionada, foi identificado que apenas $57 \%$ conheciam o manuseio do DEA. Portanto, independentemente, de ser capacitado nas manobras de RCP, o aluno deve ter conhecimento nos do correto uso do DEA.

Existem questionamentos em relação a priorização das compressões torácicas, independentemente, do DEA estar disponível, com a justificativa de haver aumento nas chances de restabelecimento espontâneo da circulação, embora não haja evidência científica que embase ou refute essa hipótese ${ }^{28}$.

Entre aqueles que responderam ter aptidão em manusear o DEA, $40 \%$ atribuíram o conhecimento à faculdade, corroborando com a relevância da iniciativa do ensino nesse campo em instituições educacionais.

Apesar da existência da lei que institucionaliza a presença do DEA em locais públicos com grande circulação de pessoas no Brasil ${ }^{17}$, apenas a metade do grupo o identificou nos ambientes públicos, sendo os shopping centers, o mais reportado. A conduta varia conforme o país, nos Estados Unidos da América, em alguns Estados, é obrigatório quehaja DEAdisponívelem determinadas áreas, já no Japão não há obrigatoriedade, porém são instalados de forma voluntária pelos donos dos locais ${ }^{29}$.

As distâncias dos locais de instalação do DEA, em locais públicos, impactam no sucesso na RCP, em conjunto com o preparo do socorrista, seja ele leigo ou treinado e, principalmente, o reconhecimento da $\mathrm{PCR}^{30,31}$. Nesse sentido, haverá redução dos intervalos de tempo entre a PCR e o início da RCP e entre a PCR e a primeira desfibrilação, principalmente, se houver promoção no treinamento da comunidade ${ }^{32}$.

Quando os alunos foram questionados sobre a diferença entre os tipos de ritmo cardíaco e a influência na conduta da PCR, o grupo demonstrou que mais da metade $(57 \%)$ desconhecia a diferença, apesar de afirmarem haver influência na decisão terapêutica. O conhecimento teórico sobre a fisiopatologia, que justificaria o uso do DEA, deve ser valorizada.

Algumas vítimas de PCR em assistolia, podem 
evoluir para ritmos cardíacos chocáveis durante a RCP, com modificação na sua sobrevivência quando avaliadas pelo DEA e submetidas à desfibrilação ${ }^{33}$. Em contrapartida, os casos identificados como não chocáveis, devem se manter recebendo as compressões torácicas até chegada do $\mathrm{SEM}^{10}$.

O melhor prognóstico durante as compressões torácicas foi relacionado, tanto à profundidade de 5 $\mathrm{cm}$ no tórax, como à velocidade, em torno de $100 \mathrm{a}$ 120 compressões por minuto, intercaladas com as ventilações em razão de com razão de 30:2, devendo haver a priorização das compressões em detrimento das ventilações, se necessário ${ }^{34-37}$.

Dois terços do grupo identificaram que a lenta velocidade e pouca profundidade das compressões torácicas reduziriam a sobrevivência. Houve três quartos de reconhecimento da correta profundidade em adultos, enquanto em crianças, apenas $10,67 \%$ demonstrou conhecimento em relação ao semelhante valor ${ }^{10}$.

Estudo realizado na Suécia observou que a sobrevida em 30 dias, após a PCR, foi maior quando aplicado apenas compressões torácicas, comparado ao tradicional ${ }^{38}$.

A maioria dos alunos demonstrou conhecimento dos números telefônicos para a solicitação do socorro como o 192 e 193. No Brasil, as ligações de pedido de socorro à PCR são recebidas por uma central telefônica, que definirá qual o tipo de equipe e viatura será disponibilizado, com base no relato ${ }^{39}$.

De uma forma geral, o SAMU é responsável por atendimentos de urgência e emergência de origem traumática, clínica ou cirúrgica, enquanto isso, o CBM por ações de salvamento, proteção de vidas através de ações de prevenção, vistoria, análises de segurança e prevenção de incêndios ${ }^{40}$.

Estudo anterior em alunos de medicina observou que aqueles matriculados no primeiro período demonstraram maior conhecimento em relação às manobras de RCP e uso do $\mathrm{DEA}^{41}$.

A implementação de oficinas de treinamento de leigos e profissionais da saúde é responsável por capacitar e aumentar os índices de sobrevivência pós $\mathrm{PCR}^{42}$.

Praticar em cenários simulados pode ajudar na fixação do conhecimento e habilidades em alunos de medicina, com consequente multiplicações desse conhecimento com grupos como os amigos ou família.

\section{Limitações}

O uso de questionário anônimo impede a ação ativa no grupo que mostrou déficit no conhecimento da RCP.

\section{Conclusão}

O presente estudo foi capaz de mostrar há uma diferença considerável entre os alunos de medicina que se consideram capazes de reconhecer uma PCR $(80,33 \%)$ e os que se considerariam aptos a atuar no atendimento $(50 \%)$.

Apesar demuitos demonstraremum conhecimento teórico satisfatório a respeito das técnicas e diretrizes, são observadas lacunas a serem preenchidas em temas mais específicos das manobras como nos casos de PCR pediátrica, evidenciando a necessidade de haver mais capacitações.

Ao identificarqueapesarde uma parte considerável dos estudantes responder corretamente sobre diversos aspectos da RCP, eles não se sentiriam seguros para colocar esse conhecimento em um atendimento real, evidenciando a necessidade de haver cenários de prática e aulas em modelos "hands-on" para ajudar na fixação e desenvolvimento de habilidades na prática.

\section{Referências}

1. American Heart Association. Heart Attack or Sudden Cardiac Arrest: How Are They Different? [Internet]. Available at: https://www.heart.org/ en/health-topics/heart-attack/about-heart-attacks/heart-attack-or-suddencardiac-arrest-how-are-they-different

2. Corliss J, Harvard Medical School. Heart attack versus cardiac arrest.

3. American Heart Association. Cardiac Arrest vs Heart Attack Infographic [Internet]. Available at: https://cpr.heart.org/en/resources/ cardiac-arrest-vs-heart-attack

4. Ministério da Saúde. Datasus doenças do aparelho circulatório [Internet]. [citado 10 de maio de 2020]. Available at: http://tabnet.datasus. gov.br/cgi/deftohtm.exe?sih/cnv/niuf.def

5. DeBard ML. The history of cardiopulmonary resuscitation. Ann Emerg Med. 1980;9(5):273-5.

6. Kucmin T, Płowaś-Goral M, Nogalski A. [A brief history of resuscitation - the influence of previous experience on modern techniques and methods]. Pol Merkur Lekarski. fevereiro de 2015;38(224):123-6.

7. History of CPR | American Heart Association CPR \& First Aid [Internet]. Available at: https://cpr.heart.org/en/resources/history-of-cpr

8. Ministério da Saúde. Painel de Monitoramento da Mortalidade DASNT - SVS/MS. Available at: http://svs.aids.gov.br/dantps/centrais-deconteudos/paineis-de-monitoramento/mortalidade/cid10/

9. Bernoche C, Timerman S, Polastri TF, Giannetti NS, Siqueira AW da S, Piscopo A, et al. Atualização da Diretriz de Ressuscitação Cardiopulmonar e Cuidados Cardiovasculares de Emergência da Sociedade Brasileira de Cardiologia. Arq Bras Cardiol 2019; 113:449-663.

10. American Heart Association. HIGHLIGHTS of the 2015 American Heart Association - Guidelines Update for CPR and ECC. 2015;

11. Lima SG de, Macedo LA de, Vidal M de L, Sá MPB de O. Educação Permanente em SBV e SAVC: impacto no conhecimento dos profissionais de enfermagem. Vol. 93, Arq Bras Cardiol 2009; 93:630-6.

12. Bocka JJ. Automatic external defibrillators. Ann Emerg Med $1989 ; 18(12): 1264-8$

13. Varon J, Marik PE. Treatment of cardiac arrest with automatic external 
defibrillators: impact on outcome. Am J Cardiovasc Drugs 2003;3(4):26570 .

14. Vanheusden LM, Santoro DC, Szpilman D, Batista C de O, Correia LF, Cruz Filho FE. Conceito fase-dependente na ressuscitação cardiopulmonar. Rev da SOCERJ. 2007;20(1):60-4.

15. Kerber RE, Becker LB, Bourland JD, Cummins RO, Hallstrom AP, Michos MB, et al. Automatic external defibrillators for public access defibrillation: recommendations for specifying and reporting arrhythmia analysis algorithm performance, incorporating new waveforms, and enhancing safety: a statement for health professionals from the Am. Circulation 1997;95(6):1677-82.

16. Cruz Fo FES, Timerman S, God EMG. Declaração de desfibrilação precoce. Arq Bras Cardiol 1997; 69:431.

17. Congresso Nacional. Obrigatoriedade do DEA [Internet]. 2004. Available at: https://www.camara.leg.br/proposicoesWeb/prop mostrarintegra?codteor $=236926$

18. Viana T. Projeto de Lei do Senado $n^{\circ} 344$, de 2003 [Internet]. 2003. Available at: https://www25.senado.leg.br/web/atividade/materias/-/ materia/60610

19. da Silva JK, Conceição DMM, Rodrigues GM, Dantas G de SV. Suporte básico de vida para leigos: relato de atividades extensionistas. Rev Ciência em Extensão. 2017;13(1):190-203.

20. Boaventura AP, Miyadahira AMK. Programa de capacitação em ressuscitação cardiorrespiratória com uso do desfibrilador externo automático em uma universidade. Rev Gau Enf. 2012;33:191-4.

21. Neto J, Brum I, Pereira D, Santos L, Moraes S, Ferreira R. Conhecimento e interesse sobre suporte básico de vida entre leigos. Int J Cardiovasc Sci. 2016;29(6):443-52.

22. Berdowski J, Beekhuis F, Zwinderman AH, Tijssen JGP, Koster RW. Importance of the first link: Description and recognition of an out-of-hospital cardiac arrest in an emergency call. Circulation. 2009;119(15):2096-102.

23. Ko SY, Shin S Do, Ro YS, Song KJ, Hong KJ, Park JH, et al. Effect of detection time interval for out-of-hospital cardiac arrest on outcomes in dispatcher-assisted cardiopulmonary resuscitation: A nationwide observational study. Resuscitation 2018;129:61-9.

24. Keeffe C, Nicholl J, Turner J, Goodacre S. Role of ambulance response times in the survival of patients with out-of-hospital cardiac arrest. Emerg Med J 2011;28(8):703 LP - 706.

25. Drennan IR, Strum RP, Byers A, Buick JE, Lin S, Cheskes S, et al. Out-of-hospital cardiac arrest in high-rise buildings: delays to patient care and effect on survival. C Can Med Assoc $\mathrm{J}=\mathrm{J}$ l'Association medicale Can. 2016;188(6):413-9.

26. Vukmir RB. Survival from prehospital cardiac arrest is critically dependent upon response time. Resuscitation 2006;69(2):229-34.

27. Gonzalez MM, Timerman S, Gianotto-Oliveira R, Polastri TF, Canesin MF, Schimidt A, et al. I Diretriz de Ressuscitação Cardiopulmonar e Cuidados Cardiovasculares de Emergência da Sociedade Brasileira de Cardiologia. Arq Bras Cardiol 2013;101:1-221.

28. Winship C, Williams B, Boyle MJ. Cardiopulmonary resuscitation before defibrillation in the out-of-hospital setting: a literature review. Emerg Med J 2012;29(10):826 LP - 829.

29. Wang T-H, Lin H-A, Kao W-F, Chao C-C. Locational effect on automated external defibrillator use and association of age with on-site return of spontaneous circulation. Am J Emerg Med. 2019;37(8):1446-9.

30. Fredman D, Haas J, Ban Y, Jonsson M, Svensson L, Djarv T, et al. Use of a geographic information system to identify differences in automated external defibrillator installation in urban areas with similar incidence of public out-of-hospital cardiac arrest: a retrospective registry-based study. BMJ Open 2017;7(5):e014801.

31. Davies CS, Colquhoun MC, Boyle R, Chamberlain DA. A national programme for on-site defibrillation by lay people in selected high risk areas: initial results. Heart 2005;91(10):1299-1302.

32. Bae H. Legal aspects of the application of the lay rescuer automatic external defibrillator 2008;34(3):299-303.

33. Olasveengen TM, Samdal M, Steen PA, Wik L, Sunde K. Progressing from initial non-shockable rhythms to a shockable rhythm is associated with improved outcome after out-of-hospital cardiac arrest. Resuscitation. 2009;80(1):24-9.

34. Anantharaman V. Chest compression-only CPR or good quality $30: 2$ CPR. Singapore Med J. 2011;52(8):576-81.

35. Ong EHM. Improving the quality of CPR in the community. Singapore Med J. 2011;52(8):586-91.

36. Kleinman ME, Brennan EE, Goldberger ZD, Swor RA, Terry M, Bobrow BJ, et al. Part 5: adult basic life support and cardiopulmonary resuscitation quality: 2015 American Heart Association guidelines update for cardiopulmonary resuscitation and emergency cardiovascular care. Circulation. 2015;132(18_suppl_2):S414-35.

37. Berg RA, Kern KB. Hands-Only Cardiopulmonary Resuscitation: Is It Really Dangerous? Respir Care. 2008;53(7):855-857.

38. Harvard Health. Hands-only CPR: A lifesaving technique within your reach [Internet]. Available at: https://www.health.harvard.edu/heart-health hands-only-cpr-a-lifesaving-technique-within-your-reach

39. Ministério da Saúde. SAMU e Corpo de Bombeiros: Saiba diferenciar os serviços [Internet]. Available at: http://www.blog.saude.gov.br/30884samu-e-corpo-de-bombeiros-saiba-diferenciar-os-servicos.html

40. Ministério da Saúde. SAMU e Corpo de Bombeiros. Em quais casos chamar? [Internet]. Available at: http://www.blog.saude.gov.br/index. $\mathrm{php} / 570$-destaques/34551-samu-e-corpo-de-bombeiros-em-quais-casoschamar

41. Marques SC, Dias DF, Aragão IPB de. Prevalência do conhecimento e aplicação das Técnicas de Ressuscitação Cardiopulmonar. 2019.

42. Villalobos F, Del Pozo A, Rey-Reñones C, Granado-Font E, SabatéLissner D, Poblet-Calaf C, et al. Lay people training in CPR and in the use of an automated external defibrillator, and its social impact: A community health study. Int J Environ Res Public Health. 2 de agosto de 2019;16(16) 